\title{
UKRAINA W POLITYCE ZAGRANICZNEJ POLSKI W DOBIE DRUGIEGO RZĄDU ZJEDNOCZONEJ PRAWICY POD EGIDĄ PRAWA I SPRAWIEDLIWOŚCI (2015-2018)
}

W klasycznym modelu państwa polityka zagraniczna - według różnych definicji - służy przede wszystkim do maksymalizacji zysków wynikających z potencjału kraju i otoczenia międzynarodowego, a więc aktualnego układu sił na świecie. Jest ona postrzegana zazwyczaj jako proces o charakterze zmiennym i dynamicznym, jako zjawisko społeczne, niezbędne państwu do istnienia i rozwoju. Takie właśnie rozumienie polityki zagranicznej, zakładającej maksymalizację sytuacji korzystnych, przy jednoczesnej minimalizacji niekorzystnych, najczęściej dominuje w literaturze politologicznej ${ }^{1}$.

Polityka zagraniczna służy zatem głównie do optymalizacji zysków wynikających z potencjału kraju, niekiedy może być także wyrazem mocarstwowego poczucia wyższości, ale też może czasem oznaczać słabość i wewnętrzne kompleksy państwa, brak doświadczenia, nieznajomość, a nawet arogancję wobec norm i instytucji, które umożliwiają mu istnienie i funkcjonowanie ${ }^{2}$. Ex definitione polityka zagraniczna realizowana przez każde państwo rozgrywa się w realiach geopolitycznych i geostrategicznych, stworzonych przez uwarunkowania zewnętrzne, zawsze jest też ona rezultatem wewnętrznego układu sił, aczkolwiek czynniki ad intra pozostają zazwyczaj na drugim planie w stosunku do domeny ad extra. Takie prawidłowości towarzyszą także w przypadku polityki zagra-

Prof. dr hab. MACIEJ MRÓz - Instytut Studiów Międzynarodowych, Uniwersytet Wrocławski; adres do korespondencji: ul. Koszarowa 3, 51-149 Wrocław; e-mail: maciej.mroz@uwr.edu.pl; ORCID iD: https://orcid.org/0000-0002-2662-1230

${ }^{1}$ Przykładowo: Polityka zagraniczna. Aktorzy, potencjały, strategie, red. T. Łoś-Nowak, Warszawa 2011. W polskim środowisku teoretyków stosunków międzynarodowych problematykę teorii polityki zagranicznej podejmują w swoich pracach od wielu lat - obok wspomnianej T. Łoś-Nowak - R. Zięba, J. Zając, S. Bieleń, J. Stefanowicz, ostatnio także B. Surmacz i inni.

${ }^{2}$ Tamże, s. 17. 
nicznej Polski, prowadzonej przez koalicję partii prawicowych w Polsce po wyborach parlamentarnych w 2015 roku. Niewątpliwie byłoby niedopuszczalnym uproszczeniem utracenie z pola widzenia udziału ludzkiej woli, zwłaszcza liderów politycznych, w mniejszym wymiarze lokalnych decydentów czy prominentnych doradców oraz zbiorowej wyobraźni i oczekiwań społeczeństwa w kształtowaniu polityki zagranicznej Polski na przestrzeni ostatnich kilkunastu miesięcy ${ }^{3}$.

W wyniku wygranych wyborów w październiku 2015 r. do władzy w Polsce doszła koalicja partii prawicowych pod przywództwem Prawa i Sprawiedliwości, zapowiadająca tzw. dobrą zmianę, także w polityce zagranicznej, polegającą m.in. na zwiększeniu podmiotowej roli Polski w Unii Europejskiej i porzuceniu nadmiernego - zdaniem polityków prawicowych - ulegania sugestiom płynącym z Berlina i Paryża, przy jednoczesnym uczynieniu z Wielkiej Brytanii czołowego partnera Warszawy w Europie ${ }^{4}$. Suwerenna polityka rządu premier Beaty Szydło wypływała $\mathrm{z}$ przyjęcia przez obóz rządzący w Polsce prymatu polityki wewnętrznej nad zagraniczną, a nawet uczynienia $z$ tej ostatniej funkcji polityki wewnętrznej. Konkludując, można wręcz stwierdzić, iż od odzyskania niepodległości i suwerenności poprzez zakończony sukcesem proces tranzycji aż do dnia dzisiejszego nigdy wcześniej polityka zagraniczna Polski nie była w takim stopniu zakładnikiem polityki wewnętrznej.

Rodzi się zatem w sposób nieuchronny pytanie: czy od czasu objęcia władzy w 2015 r. przez partie prawicowe pod egidą Prawa i Sprawiedliwości nastąpił jakościowy zwrot w polityce zagranicznej Polski i jakie były jego konsekwencje dla relacji bilateralnych z Ukrainą? Wśród zasadniczych wyróżników nowej polityki zagranicznej rządu wypada na pierwszym miejscu wymienić przesłanki ideowe i polityczne reorientacji polityki zagranicznej rządu premier Beaty Szydło, a następnie Mateusza Morawieckiego, wynikające z przekonania o postępującej dezintegracji Unii Europejskiej, wasalnej - zdaniem polityków prawicowych, na czele z Jarosławem Kaczyńskim - roli Polski wobec Berlina i Paryża 5 .

${ }^{3}$ Interesujące uwagi na temat osobowości politycznych doby tranzycji, a więc lat 1989-1992, zob. A. DudEK, System decyzyjny w polityce zagranicznej Polski w okresie tranzycji (1989-1992). Mechanizmy, procedury i instytucje praktyka, Wrocław 2012.

${ }^{4}$ Raport - Jaka zmiana? Założenia i perspektywy polityki zagranicznej rzadu PiS. Raport przygotowany przez grupę ekspertów powołaną w 2016 roku przez Fundację im. Stefana Batorego. Zadaniem tej grupy jest monitorowanie i refleksja nad polityką zagraniczną Polski. W jej skład weszły osoby związane z różnymi think tankami i organizacjami: Adam Balcer z WiseEuropa, Piotr Buras z warszawskiego biura Europejskiej Rady Spraw Zagranicznych (ECFR), Grzegorz Gromadzki z Fundacji im. Stefana Batorego oraz Eugeniusz Smolar z Centrum Stosunków Międzynarodowych.

5 Informacja ministra spraw zagranicznych Witolda Waszczykowskiego o zadaniach polskiej polityki zagranicznej w 2016 roku, www.msz.gov.pl [dostęp: 23.02.2016]. 
Kolejna kwestia w odniesieniu do polityki zagranicznej państwa to demonstracyjne odejście ekipy rządowej od ścisłej współpracy z tzw. twardym jądrem UE - Niemcami i Francją, na rzecz zacieśnienia relacji z Wielką Brytanią, Węgrami i Grupą Wyszehradzką ${ }^{6}$. Z perspektywy minionych z górą dwóch lat można postawić diagnozę, iż w efekcie działań polskiej dyplomacji nastąpiła postępująca samoizolacja i marginalizacja pozycji Polski w UE, poprzez m.in. odrzucenie lansowanej przez poprzedni rząd koncepcji, że im silniejsza Polska w UE, tym większa siła oddziaływania polityki zagranicznej, np. w stosunku do Ukrainy (Partnerstwo Wschodnie) czy też w relacjach z Rosją (Realpolitik rządu Donalda Tuska). Szczególnie niepokojąco brzmią dla Polski płynące z Brukseli sygnały o możliwości in spe powołania tzw. nowej Unii bez Polski, opartej na idei karolińskiej bądź krajach strefy euro oraz otwartej na wspólne rozwiązywanie problemu uchodźców, od którego rząd polski wyraźnie się dystansuje.

Dokonując wstępnego bilansu dotychczasowych działań rządu zjednoczonej prawicy $\mathrm{w}$ zakresie polityki zagranicznej państwa, wypada zwrócić przede wszystkim uwagę na fakt, iż koncepcja dobrej zmiany pociąga za sobą najpoważniejszą od ćwierćwiecza reorientację w sferze polityki zagranicznej, polegającą na odrzuceniu obowiązującego dotychczas konsensusu wszystkich, bez względu na barwy ideowe i przesłanki polityczne, sił politycznych w Polsce w odniesieniu do zasadniczej euroatlantyckiej orientacji III RP. Co więcej, w warstwie deklaracji polityczno-programowych opiniotwórczych przedstawicieli obozu rządzącego i bliskich mu środowisk intelektualnych, a nawet niektórych eksperckich, dobra zmiana w polityce zagranicznej ipso facto oznacza odejście od kilku aksjomatycznych pryncypiów, które kształtowały zarówno politykę państwa, jak i miały wpływ także na zbiorową wyobraźnię elit politycznych i zapewne większości społeczeństwa w Polsce po 1989 roku. Pośród wspomnianych pryncypiów na pierwszym planie sytuowało się uniknięcie przez Polskę, wyzwoloną z oków jałtańskiego porządku, znalezienia się w szarej strefie niepewności na peryferiach Europy oraz trwałe zakotwiczenie się w zachodnim systemie bezpieczeństwa, tj. w NATO, oraz w europejskich strukturach politycznych, prawnych i gospodarczych, czyli w Unii Europejskiej. Kolejnymi filarami polityki wschodniej Polski było skierowanie jej głównego wysiłku w stronę Rosji, jako największego wyzwania dla naszej dyplomacji, a tym samym udzielanie wsparcia w obronie suwerenności państw Europy Wschodniej, a najlepszą na osiągnięcie tego strategicznego celu metodą miało być integrowanie tych krajów według modelu i ścieżki, jaką przeszła Polska, od zgłoszenia gotowości wstąpie-

${ }^{6}$ Ttumacz Polski, rozmowa Adama Krzemińskiego z prezydentem Niemiec Joachimem Gauckiem, „Polityka” 2016, nr 25 (3064), 15.06-21.06, s. 21-23. 
nia aż po akcesję do Unii Europejskiej, i wreszcie - Polska winna zabiegać o silną pozycję w Brukseli, ażeby maksymalnie wpływać na jej politykę wschodnią ${ }^{7}$.

Naturalnie wśród tych problemów znajdowało się także niezmiennie polskie wsparcie dla europejskich aspiracji Ukrainy i nieco na wyrost formułowane strategiczne partnerstwo Warszawy z Kijowem. Tymczasem na naszych oczach Europa Środkowa przestała istnieć, została tylko Europa Wschodnia; Czesi, Słowacy, Węgrzy, a teraz także Polacy zachowują się tak, jak gdyby chcieli być jak najdalej od zachodniej części kontynentu. Zmniejsza to szanse Ukrainy, bo na perspektywy ukraińskiej transformacji będzie się odtąd patrzyło przez pryzmat zachowania Polaków i ich sąsiadów ${ }^{8}$. Wraz z objęciem władzy przez zjednoczoną prawicę nastąpiło swoiste wypowiedzenie przez nową ekipę rządową konsensusu, zawartego po przemianach ustrojowych, w sprawie polityki zagranicznej Polski i zasadniczych założeń polskiej racji stanu, a sama polityka zagraniczna RP stała się parasolem ochronnym dla dobrej zmiany, co w konsekwencji oznaczało prymat polityki wewnętrznej nad międzynarodową. Politykę wschodnią Polski w dobie rządów PiS charakteryzuje to, iż na wschodzie kontynentu mamy już tylko wrogów i byłych przyjaciół, a pustkę po koncepcji Giedroycia zajęła nacjonalistyczna retoryka i frazeologia, nieznosząca Ukrainy i Ukraińców, przy jednoczesnym flircie z Moskwą.

Symbolem odejścia od dotychczasowych pryncypiów było m.in. wystąpienie 20 maja 2016 r. premier Szydło w sejmie przeciwko Komisji Europejskiej i bezprecedensowy atak na opozycję czy też niecodzienna uchwała w sprawie ochrony suwerenności. Jednocześnie można było zaobserwować tzw. dyplomację publicystyczną ówczesnego szefa MSZ Witolda Waszczykowskiego, notabene zawodowego dyplomaty, najgorzej ocenianego ministra w rządzie, co w sposób naturalny wiąże się z następnym problemem poważnie wpływającym na politykę zagraniczną Polski, w tym także na relacje z Ukrainą. Jest nim niewątpliwie pozakonstytucyjny - obok prezydenta, rządu i szefa dyplomacji - ośrodek podejmowania zasadniczych decyzji w średnio i długofalowym wymiarze w odniesieniu do polityki zagranicznej RP, skupiony w rękach prezesa Prawa i Sprawiedliwości Jarosława Kaczyńskiego, mający charakter fenomenu jednorazowego, niemającego analogii we współczesnej Europie.

\footnotetext{
${ }^{7}$ Publikacja K. Pełczyńskiej-Nałęcz Pożegnanie z Giedroyciem powstała w ramach programu Otwarta Europa Fundacji im. Stefana Batorego. Zob. www.batory.org.pl [dostęp: 14.05.2018].

${ }^{8}$ Wywiad z prof. Jarosławem Hrycakiem z Ukraińskiego Uniwersytetu Katolickiego z dnia 2 XII 2016 roku, http://wyborcza.pl/7,75968,21060081,ukrainski-historyk-takiej-polski-juz-namnie-potrzeba.html [dostęp: 6.05.2018].
} 
Najbardziej charakterystyczną cechą świadczącą o prymacie polityki wewnętrznej nad zagraniczną, w wydaniu Prawa i Sprawiedliwości, jest - ponad wszelką wątpliwość - na gruncie unijnym nowa polityka zagraniczna Polski, której głównym determinantem zdaje się być postrzeganie projektu europejskiego jako schyłkowego ${ }^{9}$. Co prawda, przebieg wizyty prezydenta Donalda Trumpa w Warszawie latem 2017 roku i przemówienie na placu Krasińskich odebrane zostało jako wyraz poparcia Stanów Zjednoczonych dla Polski i podejmowanych przez nią inicjatyw, w tym Trójmorza, to jednak już wkrótce, z powodu skandalicznej nowelizacji ustawy o IPN, polityczne relacje polsko-amerykańskie uległy nagłemu pogorszeniu, a cena za dostawy uzbrojenia dla wojska polskiego znacznie wzrosła. $Z$ drugiej jednak strony informacja o skierowaniu do Europy ciężkiej amerykańskiej brygady pancernej, być może do Polski, i symboliczne zainicjowanie 13 maja 2016 r. budowy w Redzikowie elementów amerykańskiej tarczy antyrakietowej oznacza odejście USA od zapoczątkowanej po upadku ZSRR drastycznej redukcji obecności wojskowej Stanów Zjednoczonych na Starym Kontynencie. Postępujące ochłodzenie relacji polsko-amerykańskich, zwłaszcza po nowelizacji ustawy o IPN, znalazło także wyraz w notatce MSZ, której treść trafiła do mediów.

Najważniejsze znaczenie w całokształcie relacji polsko-amerykańskich mają dla Warszawy ex definitione kwestie bezpieczeństwa, dlatego też obserwatorzy zwracają baczną uwagę na relacje ze szczytu NATO w Warszawie. Politycy rządzącej partii, a za nimi kolejni szefowie dyplomacji, Waszczykowski i Jacek Czaputowicz, zdają się zapominać, iż głównym sojusznikiem USA w Europie są Niemcy, a nie Wielka Brytania czy Francja, a zatem dystansowanie się Warszawy od Berlina osłabia wybitnie miejsce Polski w polityce amerykańskiej w Europie. Ponadto $\mathrm{z}$ uwagi na rolę prasy w USA w kształtowaniu opinii administracji na temat problematyki międzynarodowej, zwłaszcza takich mediów, jak „New York Times”, „Washington Post” czy portal Politico, niezrozumiałe wydaje się zaniedbywanie przez polską dyplomację kreowania pozytywnego wizerunku kraju, a wręcz poprzez publicystyczne, a nawet obraźliwe wypowiedzi w mediach ministra Waszczykowskiego, jego podważanie w oczach opinii międzynarodowej.

Wśród nowych wektorów polityki zagranicznej Polski należy wskazać na ideę powrotu do koncepcji Międzymorza, które nagle w 2015 roku stało się

${ }^{9}$ M. Mróz, Wielki projekt matych krajów. Od Międzymorza do Trójmorza w polityce zagranicznej Polski w dobie drugiego rządu Prawa i Sprawiedliwości, w: Polityka zagraniczna Polski wobec państw, regionów i oraganiazacji, red. M. Mróz, A. Drzewicki „Dyplomacja i Bezpieczeństwo" 2017/2018, nr 1(5), s. 15-41. Z innej, zasadniczo kulturowej perspektywy na ten temat zob. Z. SzCZEREK, Międzymorze. Podróże przez prawdziwa i wyobrażona Europę Srodkowa, WołowiecWarszawa 2017. 
w retoryce obozu władzy Trójmorzem, oraz jej konsekwencje dla pozycji międzynarodowej Polski w Europie Środkowej i Wschodniej. Zdaniem rządzącej w Polsce prawicy, idea ta zasługuje na to, by mutatis mutandis stać się jednym z filarów polskiej polityki zagranicznej, komplementarnym względem orientacji na Brukselę (tj. NATO i UE). Stosunki Polski z Federacją Rosyjską są niewątpliwie najgorsze od 1989 r., i chociaż nie można na konto aktywów polityki zagranicznej Polski zapisać fiaska w kwestii stałych baz, na rzecz obecności rotacyjnej sił NATO w Europie Środkowej i Wschodniej, to paradoksalnie konflikt na Ukrainie wzmacniał zainteresowanie NATO regionem.

Tradycyjnie doniosłe znaczenie dla pozycji międzynarodowej Polski, szczególnie w wymiarze bezpieczeństwa, mają od czasów restytucji niepodległości Ukrainy stosunki Warszawy z Kijowem. Miejsce Ukrainy w polityce zagranicznej Polski w kontekście konfliktu ukraińsko-rosyjskiego systematycznie ulega osłabieniu. Rola Polski w stabilizacji regionu musi być postrzegana poprzez fakt podstawowy, streszczający się w odrzuceniu latem 2015 r. przez prezydenta Petra Poroszenkę inicjatywy prezydenta Andrzeja Dudy, związanej z poszerzeniem formatu normandzkiego. Kijów nadal uznaje Warszawę za partnera strategicznego, ale woli najważniejsze kwestie rozwiązywać w węższym gronie, z udziałem Niemiec i Francji, ale bez Polski ${ }^{10}$. Z uwagi na prymat kwestii wewnętrznych $\mathrm{w}$ stosunku do polityki zagranicznej oraz konflikt z Brukselą związany z przestrzeganiem demokracji w Polsce ośrodek decyzyjny w PiS nie będzie na szerszą skalę angażował się w działania na rzecz wspierania reform na Ukrainie, skupiając się na głośnym artykułowaniu całokształtu problematyki związanej z agresywną polityką Federacji Rosyjskiej wobec Ukrainy (działania militarne, gospodarcze, propagandowe będą krytykowane na forum międzynarodowym przez rząd RP, a więc zagrożenia w stosunku do całego regionu będą definiowane i piętnowane).

W obliczu słabnącej pozycji Polski w UE będzie malało jej zainteresowanie Ukrainą, ponadto kilkanaście ostatnich miesięcy pokazuje, iż Kijów nie jest zanadto przekonany do koncepcji większego zaangażowania Warszawy w rozwiązanie konfliktu ukraińsko-rosyjskiego i nie dostrzega potrzeby rozszerzenia formatu normandzkiego o inne kraje, w tym Polskę.

\footnotetext{
${ }^{10}$ Szerzej na ten temat zob. M. MRÓz, Nowe wektory polityki zagranicznej Polski po wyborach 2015 r. i ich konsekwencje dla relacji Polska-Ukraina, „Visnyk of the Lviv University. Series International Relations" (Lviv) 2016, nr 38, cz. 4, s. 18-25. Ostatnio także: W. KonOŃCZUK, Czas na doktryne postgiedrojciowska wobec Ukrainy, „Nowa Europa Wschodnia” 1(2018), s. 23-37.
} 
Już w czasie trwania w Polsce koalicji PO-PSL, zwłaszcza w drugiej kadencji (2011-2015), znaczenie Ukrainy w polityce zagranicznej Polski słabło ${ }^{11}$. Dziś Warszawa, zmniejszając temperaturę relacji z Brukselą, sama w perspektywie długofalowej (nowa zintegrowana Unia wokół Niemiec i Francji) zmierza w stronę szarej strefy, pozycjonując się poza głównym obszarem stosunków międzynarodowych. W kontekście polityki zagranicznej polityczna suwerenność Polski w Unii Europejskiej, głoszona przez prezesa Prawa i Sprawiedliwości Jarosława Kaczyńskiego, wydaje się anachroniczna, a wywodząca wprost z XIX-wiecznego rozumienia kategorii państwa, narodu czy suwerenności w szczególności. Dla porównania należy podzielić trafną opinię Stanisława Bielenia, że dla USA priorytetem demokracji jest wolność, dla demokracji europejskiej równość, to dla Rosji, a także i Polski, za główny czynnik składowy demokracji suwerennej należy uznać bezpieczeństwo ${ }^{12}$. Naturalnie bezpieczeństwo rozumiane inaczej w Moskwie, a inaczej w Warszawie.

Konkludując, dotychczasowy model relacji polsko-ukraińskich dobiega końca, a to oznacza ostateczne w klasycznym rozumieniu pogrzebanie przez Warszawę idei wywodzącej się z kręgu „Paryskiej Kultury” ULB i przejście Polski do realizacji wizji quasi-mocarstwowości i Trójmorza ${ }^{13}$. Zatem koncepcja powrotu do powstałej w innych realiach polityczno-militarnych piłsudczykowskiej idei Międzymorza, anachronicznej w swojej warstwie historycznej i merytorycznej, niezrealizowanej z uwagi na nierozwiązywalny węzeł sprzeczności i antagonizmów narodowych oraz rozbieżne ambicje terytorialne państw środkowoeuropejskich doby powersalskiej, została podjęta w nowej formule jako osobliwe, wręcz kuriozalne wyzwanie dla polskiej dyplomacji po zwycięskich dla obozu prawicy wyborach 2015 roku.

W optyce polskiego MSZ, pod kierownictwem ministra Waszczykowskiego, a po reorganizacji rządu - Czaputowicza, Federacja Rosyjska zajmuje czołowe miejsce pośród państw dążących do zmiany kruchego w świecie status quo i poprzez swoją agresywną politykę wobec Ukrainy zagraża bezpośrednio bezpieczeństwu Polski ${ }^{14}$. Tak zdefiniowana ocena położenia międzynarodowego

${ }^{11}$ M. MRÓz, Między Polska piastowska a jagiellońska. Kontrowersje wokół kierunków realizacji polskiej polityki zagranicznej po akcesji do Unii Europejskiej, w: Polska polityka wschodnia, red. M. Mróz, „Dyplomacja i Bezpieczeństwo” 2013, nr 1(1), s. 27-28.

12 S. BIELEŃ, Panrosjanizm w rosyjskiej tożsamości mocarstwowo-imperialnej, w: Konflikty zbrojne na Ukrainie i Bliskim Wschodzie: nowe wyzwania dla międzynarodowego bezpieczeństwa, red. M. Mróz, „Dyplomacja i Bezpieczeństwo” 2015, nr 1(3), s. 87.

${ }^{13} \mathrm{Na}$ ten temat zob. J. OBREMSKI, Zagrożenia i szanse, „Nowa Europa Wschodnia” 1(2018), s. 41.

${ }^{14}$ Informacja ministra spraw zagranicznych Witolda Waszczykowskiego, a także Wystapienie ministra Jacka Czaputowicza o priorytetach polskiej dyplomacji wygłoszone 21 marca 2018 roku, www.msz.gov.pl [dostęp: 19.04.2018]. 
Polski wyklucza - w optyce polskiej dyplomacji - miejsce na skomplikowaną grę krzyżujących się interesów z Rosją i prowadzenie polityki na różnych poziomach, zawężając pole manewru wyłącznie do prawie kompletnej i permanentnej blokady wszelkich relacji, przy jednoczesnym niebraniu pod uwagę sedna polityki, a więc skuteczności w realizacji zamierzonych celów, a jedynie posiadania emocjonalnego poczucia przewagi i satysfakcji moralnej. Kierowanie się takimi przesłankami niemal zawsze przynosiło porażki i marginalizację, a historia dyplomacji dostarcza aż nadto wiele przykładów na poparcie tej tezy. Nie należy przecież zapominać, iż relacje Polski z Rosją to także element niezwykle skomplikowanej szarady, z wojną rosyjsko-ukraińską w pobliżu wschodnich granic RP, będącą elementem konfrontacji Moskwy z Zachodem, a w konsekwencji wynikających z tego wyzwań w zakresie bezpieczeństwa, przed którymi stanęliśmy po raz pierwszy po 1989 roku. Zatem z bezspornego faktu, iż Rosja staje się coraz bardziej niebezpiecznym sąsiadem, gdyż jest coraz bardziej autorytarna, a NATO i Unia Europejska stają się coraz słabszym gwarantem stabilizacji i bezpieczeństwa, wynika dla polskiej dyplomacji konieczność wzmacniania struktur euroatlantyckich i udzielanie wsparcia tendencjom demokratycznym i wolnościowym na Ukrainie, a nie - poprzez konflikt z liderami wspólnoty - podważanie i tak kruchej stabilizacji na kontynencie.

Ważnym zadaniem, przed którym stanie polska dyplomacja w kontekście relacji Ukraina-Polska, będzie przekonanie unijnych partnerów o konieczności przedłużenia sankcji wobec Rosji, ponieważ od dłuższego czasu można zaobserwować presję, wywieraną na rządy np. Niemiec i Francji, aby stopniowo wycofywać się z nich w miarę postępów w implementacji porozumień z Mińska, a nie po ich całkowitym wprowadzeniu w życie. Paradoksalnie najpoważniejszym sojusznikiem Polski w kwestii kontynuowania sankcji wobec Rosji, wbrew immamentnej antyniemieckiej fobii liderów Prawa i Sprawiedliwości, zdaje się być kanclerz Angela Merkel, której polityka wobec Ukrainy pozostaje niezmienna. Niemiecka dyplomacja na kierunku wschodnioeuropejskim kładzie nacisk na prezentowanie jasnego stanowiska wobec naruszenia przez Kreml prawa międzynarodowego, przy jednoczesnym dążeniu do kontynuowania dialogu i zachęcaniu obu stron do zajęcia miejsca przy negocjacyjnym stole ${ }^{15}$. Tymczasem Polska, oddalając się od Berlina, spowodowała dekompozycję osi Berlin-Warszawa, tak silnej za czasów rządów koalicji Platformy Obywatelskiej i Polskiego Stronnictwa Ludowego, która - w ocenie wielu ukraińskich komentatorów - pozostaje nadal kluczem do utrzymania wielkości Europy. Co więcej, w Kijowie liczono na to, iż Polska jako poważny gracz, myślący w kategoriach strategicznych, będzie

15 Ttumacz Polski, s. 23. 
dążyć do tego, aby tę oś przedłużyć do Paryża. Dziś ten projekt został odłożony do lamusa; Trójkąt Weimarski od dawna nie funkcjonuje, a Europa przestaje być jednolitą przestrzenią polityczną, zmieniając się w konglomerat pojedynczych krajów ze swoimi regionalnymi problemami. Dla niepodległej Polski, która umacnianie państwowości i suwerenności Ukrainy uważa za rzecz fundamentalną, ustępstwa w sprawie sankcji wobec Rosji mogą być równie trudne do zaakceptowania, co gorsza - niemożliwe do zablokowania przez polską dyplomację, aczkolwiek kwestia kontynuowania sankcji wobec Rosji była jednym z wiodących tematów rozmów kanclerz Merkel przeprowadzonych w lutym 2017 i w marcu 2018 roku w Warszawie.

Przechodząc do bardziej ogólnej oceny polskiej polityki wschodniej w dobie ponad dwuletnich rządów prawicowej koalicji pod przywództwem PiS, wypada jednoznacznie sformułować tezę o definitywnym odejściu obecnej ekipy od założeń, które przyświecały przez blisko ćwierćwiecze polskiej polityce wobec wschodnioeuropejskich sąsiadów, wśród których naczelnym aksjomatem było przyjęcie tezy, iż nie ma wolnej Polski bez niepodległej Ukrainy, Litwy i Białorusi. W ramach realizowanej przez Polskę polityki wschodniej udzielano wówczas wsparcia dla procesów demokratyzacyjnych i reform państwa, tworzenia nowoczesnych instytucji państwowych, promocji praw człowieka oraz wieloaspektowej pomocy w budowie społeczeństwa obywatelskiego, zwłaszcza na Ukrainie. Praktyka polityczna wskazuje jednak, iż wbrew formalnym zapisom i werbalnym zapewnieniom w polskiej polityce wschodniej dokonuje się dalekosiężna, wręcz rewolucyjna zmiana, polegająca na tym, że wsparcie demokracji we wschodnim sąsiedztwie przestaje być priorytetem, a na pierwszy plan wysuwa się kwestia promocji polskości. Odchodzeniu od polityki wsparcia demokratyzacji towarzyszy przekonanie o konieczności wzmocnienia opieki nad Polonią i Polakami za granicą, zwłaszcza nad rodakami z Europy Wschodniej. Realizacją tych zapowiedzi była chociażby nowelizacja ustawy o Karcie Polaka ${ }^{16}$.

$\mathrm{W}$ przypadku relacji z Ukrainą, z uwagi na imperialną politykę Moskwy, szczególnego znaczenia nabiera konstelacja sił w naszym najbliższym otoczeniu, chociażby przez wzgląd na brak samowystarczalności Polski w kwestii bezpieczeństwa. W tej sytuacji niepodległość państw oddzielających Polskę od Federacji Rosyjskiej, a zwłaszcza Ukrainy, jest kluczowym czynnikiem, który stanowi zaporę dla realizacji coraz aktywniej artykułowanej przez Kreml koncepcji ograniczonej suwerenności krajów z nią sąsiadujących. Ta niezwykle groźna, zaktualizowana w 2014 roku, doktryna forsuje prawo Rosji do blokowania tych decyzji sąsiadów (tzw. bliskiej zagranicy), które według Moskwy zagrażają jej

\footnotetext{
${ }^{16}$ K. PeŁCZYŃSKA-NaŁęCZ, Pożegnanie z Giedroyciem, s. 7.
} 
bezpieczeństwu. Federacja Rosyjska zakłada możliwość podjęcia interwencji, także militarnej, wobec państw ościennych, w przypadku gdy ich polityka będzie sprzeczna z interesem Moskwy. Do tych zagrożeń dla rosyjskiej racji stanu zaliczono w nowej doktrynie m.in. pojawienie się na terytorium państw sąsiedzkich napięć o charakterze wyznaniowym, uzbrojonych radykalnych ugrupowań czy też prywatnych formacji wojskowych. Oznacza to de facto powrót Europy Wschodniej, przy milczącej zgodzie państw zachodnich, do koncepcji ograniczonej suwerenności, o czym na warszawskim szczycie NATO przekonały się Ukraina i Gruzja, nie dostając zaproszenia ani do NATO, ani do Unii Europejskiej.

Dynamika zmian sytuacji międzynarodowej na świecie i wokół Polski sprawia, iż przed polską dyplomacją stają wyzwania, które jeszcze niedawno uważane były za przejaw futurologicznej histerii, a które dziś wymagają prowadzenia wyrafinowanej i wolnej od fobii polityki zagranicznej oraz przysłowiowej gry na wielu instrumentach jednocześnie. Dlatego też zaniechanie przez Warszawę wsparcia demokracji w Europie Wschodniej, a w szczególności na Ukrainie, należy rozpatrywać w kategoriach niezgodnych z polską racją stanu i interesem bezpieczeństwa państwa.

Do poważnej modyfikacji, a nawet do faktycznego zerwania z koncepcjami Giedroycia i Mieroszewskiego doszło w polityce wschodniej Polski, szczególnie widocznych w relacjach z Ukrainą. Działania podejmowane przez polską dyplomację były odpowiedzią Warszawy na odrzucenie przez Kijów propozycji prezydenta Andrzeja Dudy w kwestii poszerzenia formatu normandzkiego, także o Polskę, ergo z uwagi na prymat kwestii wewnętrznych w stosunku do polityki zagranicznej oraz konflikt z Brukselą związany z przestrzeganiem demokracji w Polsce, ośrodek decyzyjny w PiS zmniejsza swoją aktywność na tym polu, nie angażując się na szerszą skalę $\mathrm{w}$ działania na rzecz wspierania reform na Ukrainie. W obliczu słabnącej pozycji Polski w Unii Europejskiej będzie malało jej zainteresowanie Ukrainą, ponadto kilkanaście ostatnich miesięcy pokazuje, iż Kijów nie jest zanadto przekonany do koncepcji większego zaangażowania Warszawy w rozwiązanie konfliktu ukraińsko-rosyjskiego.

W dość powszechniej ocenie formułowanej w Kijowie Polska do 2014 roku była jednym $\mathrm{z}$ największych europejskich graczy, krajem stabilnym zarówno gospodarczo, jak i politycznie, aspirującym do roli lidera całego regionu. Od 2015 roku, po kilkunastu miesiącach rządów zjednoczonej prawicy, analitycy ukraińscy dostrzegają narastający proces degradacji Polski w Europie (podobnie jak znaną z lat 2005-2007 samoizolację Polski), a zatem oceniają Polskę jako 
państwo prowadzące tzw. małą politykę, podczas gdy we współczesnym świecie liczą się wielkie rozmiary i plany ${ }^{17}$.

Można zatem przyjąć, iż dotychczasowy model relacji polsko-ukraińskich dobiega końca, a nowy znajduje się w fazie in statu nascendi. Ujmując sprawę plastycznie, podczas gdy Kijów podąża tradycyjnym szlakiem na Zachód - idzie w stronę Berlina, to Warszawa dokonuje zwrotu o 180 stopni i się od niego oddala - podążając na Wschód. Zatem wydaje się, iż na tym polega zasadnicza sprzeczność podstawowych, także politycznych, interesów Kijowa i Warszawy pod rządami PiS. Podczas gdy Ukraina szuka sposobów na integrację i potrzebuje silnej Europy na drodze wzmocnienia wspólnoty europejskiej, ale też argumentów przeciwko eurosceptykom, Polska pod rządami koalicji skupionej wokół PiS kroczy coraz śmielej w stronę eurosceptycyzmu i podważania spójności Unii Europejskiej, chociaż wahadło europejskiej polityki po wyborach w Austrii, Holandii, a zwłaszcza we Francji, ponownie wychyla się w stronę centrum.

Dzisiejsza Polska, odwracając się plecami od europejskiego twardego jądra, a zatem od Niemiec i Francji, liczy na zrozumienie wśród sojuszników w regionie, co - zdaniem wielu ukraińskich publicystów - prowadzi do tego, iż z dotychczasowego nieformalnego lidera Europy Środkowo-Wschodniej staje się jednym z problemów Unii, jak Węgry czy Grecja. Tracąca prestiż i znaczenie Polska przestaje być także atrakcyjnym partnerem dla Ukrainy, a co gorsza przykładem udanych reform i transformacji. Wzajemne relacje wkroczyły w najgorszy po restytucji niepodległości Ukrainy okres, wyraźnie zaogniając się za sprawą przeprowadzonej w styczniu 2018 roku nowelizacji ustawy o Instytucie Pamięci Narodowej, która spowodowała gwałtowne protesty na Ukrainie. Po raz kolejny pamięć historyczna odcisnęła się głębokim piętnem na stosunkach ukraińsko-polskich, wywołując z oczywistych względów zadowolenie w rosyjskich kręgach rządowych i opiniotwórczych.

Niespotykanej wręcz wymowy nabiera w tym kontekście wiadomość o tym, iż grupa amerykańskich kongresmenów wystosowała apel do Departamentu Stanu o skłonienie rządów Ukrainy i Polski do bardziej efektywnej walki antysemityzmem ${ }^{18}$. Kongresmeni wytoczyli przeciw Polsce bardzo ciężkie działa, gdyż domagać się mieli od polskich oraz ukraińskich władz bezwarunkowego potępienia antysemityzmu oraz bezwzględnego ścigania przestępstw o charakterze

\footnotetext{
${ }^{17}$ Wywiad z prof. Jarosławem Hrycakiem, http://wyborcza.pl [dostęp: 6.05.2018].

${ }^{18}$ Pod listem podpisało się 56 kongresmenów, w tym przywódca demokratycznej mniejszości w senacie senator Chuck Schumer, a także demokrata z Nowego Jorku i wpływowy republikanin, dotychczas przyjazny Polsce, senator John McCain.
} 
antysemickim ${ }^{19}$. W liście podkreślono, że „Kongres USA od dawna wspiera Polskę i Ukrainę w budowaniu demokratycznych społeczeństw, jednak politycy są zaniepokojeni tym, że wzrost antysemityzmu i zaprzeczanie przeszłości utrudnią rozwój demokracji w tych krajach i uniemożliwią Polsce i Ukrainie budowę otwartych społeczeństw dla wszystkich swoich obywateli, tych z i bez żydowskiego pochodzenia" ${ }^{20}$.

Rzecz charakterystyczna amerykańscy kongresmeni zwrócili się także o szczegóły działań podejmowanych przez Stany Zjednoczone w zakresie monitorowania przypadków negowania Holocaustu. W liście wspomniana jest też nowelizacja ustawy o IPN, której w opinii sygnatariuszy towarzyszyły różne antysemickie wystąpienia ${ }^{21}$.

List amerykańskich senatorów z 23 kwietnia 2018 roku ipso facto stawia na jednej szali Polskę, do niedawna lidera zmian w Europie Środkowej i Wschodniej, a zarazem przykład postępującej modernizacji oraz awansu cywilizacyjnego i udanej tranzycji, z Ukrainą - trawioną przez korupcję, pogrążoną w wojnie, a przede wszystkim walczącą o przetrwanie i zachowanie niezależnej państwowości. Oficjalna odpowiedź polskiego rządu, co warte podkreślenia, utrzymana w koncyliacyjnym tonie, nie zmienia faktu, iż akcje Polski za oceanem wyraźnie słabną, a nader wysokie koszty zakupu amerykańskiego uzbrojenia zdają się potwierdzać tę diagnozę.

Ponad dwuletni okres sprawowania władzy w Polsce przez koalicję partii prawicowych przyniósł ze sobą bezprecedensowy spadek znaczenia kraju na scenie międzynarodowej polityki i dyplomacji. Nieustannie generowane przez rządzącą prawicę napięcia w relacjach $\mathrm{z}$ dotychczasowymi sojusznikami w Unii Europejskiej, a nawet w NATO powodują pozycjonowanie się RP poza głównym nurtem polityki międzynarodowej, spychając ją eo ipso na obrzeża, zarezerwowane dotąd dla państw aspirujących do członkostwa w organizacjach europejskich i euroatlantyckich.

${ }^{19}$ W Izbie Reprezentantów zakończyła się zbiórka podpisów pod listem do Johna Sullivana, zastępcy sekretarza stanu USA, który do czasu objęcia stanowiska przez Michaela Pompeo kierował amerykańską dyplomacją. Inicjatorami akcji było dwóch kongresmenów: Ro Khanna oraz David Cicilline. Amerykańscy politycy mieli stwierdzić, iż pomimo składanych kanałami dyplomatycznymi zapewnień przez prezydenta Andrzeja Dudę, że nowelizacja ustawy o IPN nie będzie ograniczała wolności słowa, złożony został pozew przeciwko gazecie w Argentynie, a wiceminister spraw zagranicznych Jan Dziedziczak zażądał od Instytutu Yad Vashem w Jerozolimie zmiany wystawy, z kolei burmistrz z Izraela został zmuszony do odwołania uroczystości przez polskie lokalne władze, ponieważ nie chciał zmienić treści wystąpienia, zawierającej fragmenty poświęcone współudziałowi Polaków w Holocauście.

${ }^{20}$ Tamże.

${ }^{21}$ Tamże. 
Z punktu widzenia Ukrainy wyraźnie dostrzec można symptomy utraty przez Kijów zainteresowania prowadzoną przez obóz prawicowy Polską, wyjmującą z zakurzonego kufra mocarstwowe koncepty, podczas gdy w Unii Europejskiej rozpoczyna się wielka debata nad przyszłością wspólnoty. Pogrążona w wojnie z Federacją Rosyjską, Ukraina nie widzi już w Warszawie strategicznego partnera, przenosząc do Berlina i Paryża swoje nadzieje na przyszłość, chociaż - niejako wbrew wielkiej polityce - Polska staje się dla z górą miliona Ukraińców miejscem pracy, a z czasem także miejscem osiedlenia i stałego zamieszkania. Skomplikowany charakter relacji polsko-ukraińskich, mocno zabarwiony doświadczeniami historycznymi i uwikłany w bieżącą politykę, w tym również międzynarodową, czeka zatem w niedalekiej przyszłości na coraz bardziej inspirowany przez Rosję przełom, którego konsekwencje dla obu krajów są trudne do przewidzenia.

\section{BIBLIOGRAFIA}

BIELEŃ S., Panrosjanizm w rosyjskiej tożsamości mocarstwowo-imperialnej, w: Konflikty zbrojne na Ukrainie i Bliskim Wschodzie: nowe wyzwania dla międzynarodowego bezpieczeństwa, red. M. Mróz, „Dyplomacja i Bezpieczeństwo” 2015, nr 1(3), s. 79-94.

DudeK A., System decyzyjny w polityce zagranicznej Polski w okresie tranzycji (1989-1992). Mechanizmy, procedury i instytucje praktyka, Wrocław 2012.

KonońcZuK W., Czas na doktrynę postgiedrojciowską wobec Ukrainy, „Nowa Europa Wschodnia" 1(2018)

Mróz M., Między Polską piastowską a jagiellońską. Kontrowersje wokół kierunków realizacji polskiej polityki zagranicznej po akcesji do Unii Europejskiej, w: Polska polityka wschodnia, red. M. Mróz, „Dyplomacja i Bezpieczeństwo” 2013, nr 1(1), s. 15-30.

Mróz M., Nowe wektory polityki zagranicznej Polski po wyborach 2015 r. i ich konsekwencje dla relacji Polska-Ukraina, „Visnyk of the Lviv University. Series International Relations” (Lviv) 2016, nr 38, cz. 4.

MRÓz M., Wielki projekt małych krajów. Od Międzymorza do Trójmorza w polityce zagranicznej Polski w dobie drugiego rządu Prawa i Sprawiedliwości, w: Polityka zagraniczna Polski wobec państw, regionów i organizacji, red. M. Mróz, A. Drzewicki, „Dyplomacja i Bezpieczeństwo" 2017/2018, nr 1(5), s. 15-41.

OBREMSKi J., Zagrożenia i szanse, „Nowa Europa Wschodnia” 1(2018).

PelcZyŃSKA-NaŁĘCZ K., Pożegnanie z Giedroyciem, www.batory.org.pl [dostęp: 14.05.2018], s. 7. Polityka zagraniczna. Aktorzy, potencjały, strategie, red. T. Łoś-Nowak, Warszawa 2011.

SzczereK Z., Międzymorze. Podróże przez prawdziwą i wyobrażoną Europę Środkową, Wołowiec-Warszawa 2017. 


\title{
UKRAINA W POLITYCE ZAGRANICZNEJ POLSKI \\ W DOBIE DRUGIEGO RZĄDU ZJEDNOCZONEJ PRAWICY \\ POD EGIDĄ PRAWA I SPRAWIEDLIWOŚCI (2015-2018)
}

\begin{abstract}
Streszczenie
Dotychczasowy model relacji polsko-ukraińskich dobiega końca, a nowy znajduje się w fazie in statu nascendi. Zasadnicza sprzeczność podstawowych interesów Kijowa i Warszawy sprowadza się do tego, że podczas gdy Ukraina szuka sposobów na integrację i potrzebuje silnej Europy oraz ipso facto wzmocnienia wspólnoty europejskiej, Polska pod rządami koalicji skupionej wokół PiS kroczy coraz śmielej w stronę eurosceptycyzmu i podważania spójności Unii Europejskiej, chociaż wahadło europejskiej polityki po wyborach w Austrii, Holandii, a zwłaszcza we Francji w 2017 r. ponownie wychyla się w stronę centrum. Dzisiejsza Polska, odwracając się plecami od europejskiego twardego jądra, a zatem od Niemiec i Francji, przestaje być także atrakcyjnym partnerem dla Ukrainy, która z kolei widząc słabnącą pozycję Polski, zacieśnia związki z Berlinem.
\end{abstract}

Slowa kluczowe: Polska; Ukraina; Unia Europejska; NATO; Stany Zjednoczone Ameryki; Federacja Rosyjska; Międzymorze; Republika Federalna Niemiec.

\section{UKRAINE IN THE POLAND'S FOREIGN POLICY IN THE ERA OF THE SECOND GOVERNMENT OF THE UNITED RIGHT WING UNDER THE AEGIS OF THE LAW AND JUSTICE PARTY (2015-2018)}

\section{S u m m ary}

The current model of Polish-Ukrainian relations is drawing to an end, while the new one is in the statu nascendi stage. The fundamental contradiction between the basic interests of Kiev and Warsaw consists in the fact that while Ukraine is seeking ways of integrating with the EU and needs a strong Europe as well as ipso facto strengthening the European community, Poland under the rule of the PiS-led coalition is heading towards Euro-skepticism and undermining cohesion of the European Union, even though after elections in Austria, the Netherlands and France in 2017 in particular, pendulum of the European policy is leaning towards the centre again. The present-day Poland, by turning its back on the European hard core, i.e. Germany and France, ceases to be an attractive partner for Ukraine, which in its turn is strengthening ties with Berlin due to Poland's faltering position.

Key words: Poland; Ukraine; the European Union; NATO; the United States of America; the Russian Federation; the Federal Republic of Germany; Intermarium. 